\title{
Alternatives to animal use in veterinary education: A growing debate
}

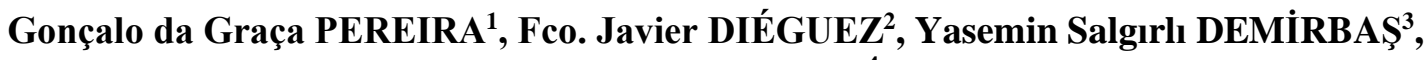 \\ Andre MENACHE ${ }^{4}$
}

\begin{abstract}
${ }^{1}$ Escola Superior Agrária de Elvas, Instituto Politécnico de Portalegre, Elvas, Center of Animal Science Studies (CECA), Institute of Sciences, Technologies and Agroenvironment (ICETA), University of Porto (UP), Porto Portugal; ${ }^{2}$ Santiago de Compostela University, Veterinary Faculty, Department of Anatomy and Animal Production, Lugo, Spain $;^{3}$ Ankara University, Faculty of Veterinary Medicine, Department of Physiology, Ankara, Turkey; ${ }^{4}$ Antidote Europe 25 rue Jacques Callot Perpignan, France.
\end{abstract}

Summary: There is a strong case to be made to teach veterinary students without resorting to the use of animals in teaching in the first place, although some authorities may disagree. It is worth examining this issue in light of new developments and new knowledge in the field of cognitive animal ethology as well as a general increase in awareness and concern for animal welfare. The teaching of concepts related to bioethics and animal welfare is increasingly relevant to modern day veterinary medicine. Unfortunately, some veterinary faculties do not emphasize these topics in their curricula. The authors consider that it is possible to largely replace animals in teaching, with other modalities. Transition from the use of replacement modalities, such as the handling of synthetic tissues, to treating living animals should be gradual and be complemented by exposure to a clinical environment in which real animal patients will benefit from the practice. The initial basic courses and procedures should include the use of synthetic models and computer simulations, followed by the study of ethically sourced animal cadavers. Only after this stage should the student be exposed to real patients. This pedagogic approach will allow the student to obtain the necessary skills required for clinical medicine, in addition to fostering a respect for sentient beings. The combination of good clinical skills and a respect for life will contribute in a positive way to raising professional and ethical standards in the profession for the benefit of all concerned.

Keywords: Animal use, education, non-animal methods, veterinary medicine.

\section{Veteriner hekimliği eğitiminde hayvan kullanımına alternatif yöntemler: Büyüyen bir tartışma}

Özet: Bazı otoriteler farklı düşünse de, veteriner hekimliği eğitiminde öğrencilerin öncelikli olarak hayvan kullanmadan öğrenim görebileceği tezi sağlam temellere dayandırılabilir. Bu konu bilişsel hayvan etolojisi alanında yeni bilgi ve gelişmeler ile hayvan refahı konusunda artan farkındalık ve endişelerin ışığında incelenmeye değerdir. Biyoetik ve hayvan refahına ilişkin kavramların öğretilmesi günümüz veteriner hekimliği ile gittikçe bağlantılı hale gelmiştir. Ancak bazı veteriner fakültelerinin eğitim programlarında bu konu üzerinde yeterince durulmamaktadır. Araştırmacılar, veteriner hekimliği eğitiminde hayvan kullanımına en iyi alternatifin bunların yerini alabilecek diğer metotların kullanılması olduğunu düşünmektedir. Sentetik dokular gibi alternatif yöntemlerden aşamalı olarak canlı hayvan tedavisi ve gerçek hastaların olduğu klinik ortama geçiş, pratik uygulamalar açısından oldukça faydalı olacaktır. Başlangıç dersleri ve prosedürlerin sentetik modeller ve bilgisayar simulasyonları ile yürütülmesi, sonrasında etik açıdan uygun şekilde elde edilmiş kadavralar üzerinde devam ettirilmesi gereklidir. Öğrencilerin gerçek hastalarla bu aşamadan sonra karşılaşmaları uygun olacaktır. Bu pedagojik yaklaşım, klinik hekimlik için öğrencinin gerekli becerileri kazanmasını sağlamasının ötesinde onlara "hisseden varlıklara" saygılı olmayı da öğretecektir. İyi klinik beceri ve yaşama saygı kombinasyonu profesyonelliğin ve etik standartların artması üzerine olumlu katkılar sağlayacaktır.

Anahtar sözcükler: Eğitim, hayvan kullanımı, hayvan kullanılmayan yöntemler, veteriner hekimliği.

\section{Introduction}

A fundamental role of the veterinarian is the welfare and protection of animals. In the eyes of the general public, the relief of pain and suffering of animals as a duty of care is expected of the profession whenever treatment is administered to an animal patient. Although many students choose this profession based on motives of compassion for sentient beings, some individuals will subsequently avoid enrolling for veterinary studies because the course work will typically involve the killing of animals for dissection and/or use of live animals to demonstrate a variety of biological principles and teach clinical skills. Animals used or harmed in this way not only dissuade potential students, but it could also be argued that such animal use is contrary to the ethics of the profession (1). Indeed, the EU Directive 2010/63/EU, 
states that "the use of animals for scientific or educational purposes should therefore only be considered where a nonanimal alternative is unavailable" (2)

Those who defend the indiscriminate use of animals in the context of veterinary education justify their position by claiming that such practices will better enable students to understand subjects such as anatomy and physiology, in addition to improving clinical and surgical skills. However, there are other ways to achieve these objectives using a different paradigm, which promotes high ethical standards, yet still provide the student with the necessary practical knowledge and skills required to produce competent professionals (17). Scientific knowledge and clinical competence are not the only skills required to produce outstanding veterinary surgeons; as professionals, veterinarians also require a significant level of understanding of animal behavior in order to recognize aspects of pain and emotion associated with states of distress (22).

The modern veterinarian should be aware of the rapidly increasing societal interest in animal ethics. This change in perspective of how we view animals can be ascribed to an increase in our awareness of compassion, which unfortunately may be crushed when confronted with the use of animals in veterinary education. This article will therefore cover some of the alternative teaching methods that are designed to adequately prepare the student in the context of veterinary medicine and surgery, through humane education.

\section{An ethical framework is an essential tool for clinical practice}

Does increased ethical awareness improve veterinary performance in the diagnosis and management of the animal patient? Significant research in the field of ethology suggests that empathy can be considered an assessment tool to better interpret animal behavior and symptoms $(4,5)$. A veterinarian who is genuinely interested in the welfare of the animal patient will be motivated to inform and help (and when this is not possible, to report) in cases of health problems that are related to the owner and/or the environment, such as poor housing conditions, inadequate primary knowledge (especially with regard to the animal's behavior and basic needs) as well as care for the neglected animal. More than any other profession, veterinary surgeons need to understand how nonhuman sentient beings feel and why, and to act in accordance with this knowledge, in order to improve the animal's situation (22). An internet survey available on the animalnetwork.com website indicates that pet owners consider the veterinary profession to be the most compassionate in comparison with seven other professions. Compassion and care are not merely personality traits but are characteristics that are crucial to the performance of a veterinarian. These traits are also useful to better prevent, diagnose and cure disease. For these reasons, they should be seen as clinical skills that every veterinarian should be taught and encouraged to develop. Maintaining a distance between healer and patient is, by definition, contrary to the practice of compassion and will likely prevent an understanding of the suffering of other sentient beings. Some studies show a correlation between the use of painkillers and attitudes toward animals (20). A diligent approach, as opposed to an indifferent approach, will likely cause less stress to the patient during the clinical examination. Iatrogenic induced stress may mask symptoms and result in a less accurate diagnosis (22). A professional attitude devoid of ethics and compassion may result in missing or incorrectly interpreting symptoms, even to the point where the animal tries to mask or hide its symptoms. It is therefore of paramount importance that the clinical examination itself is not responsible for causing unnecessary fear to the animal.

\section{The use of animals in veterinary education: are we teaching indifference? \\ By inculcating and applying principles of} compassion and care to improve animal welfare, humane education can achieve a more prominent role in the veterinary profession. In some universities the subject has been largely ignored $(10,19,21,24)$ and in other cases, the opposite is true $(6,7,11,12,19,27,28,33)$. Thus, depending on the university curriculum, potentially outstanding students with a strong caring attitude may decide not to enroll in veterinary medicine, or conversely, may decide to leave the course before completion $(6,7$, $14,16,27,28)$. Many students are highly motivated and keen to use their clinical and surgical skills for the benefit of animals, having chosen the veterinary profession based on a strong sense of compassion $(29,31,36)$. The use of teaching methods that involve animal suffering, may also bring about a desensitization of the student (an obstacle to compassion), particularly once the student becomes accustomed to, and accepts, the instrumental use of animals (23). A clear deterioration in compassionate attitudes has been shown in qualitative studies, in addition to decreased sensitivity to animal suffering as students near completion of their studies, all of which clearly suggests a negative impact inherent in the education system (35). This desensitization process is seen by some teachers as an educational objective, aimed at better preparing students for the "real world" or else to "harden themselves," creating a scenario where the animal is seen merely as an "object of study "or a" tool" instead of being seen as a sentient individual or a patient (23). This 
educational aim appears to be more motivated by the convenience of certain attitudes toward the use of animals than the need to create caring professionals.

\section{Definition and types of alternatives}

Many scientists in the context of animal research currently implement the 3Rs principle of Reduction, Replacement and Refinement alternatives as defined by Russell and Burch (30). Apart from the ethical issues, the use of alternative approaches that improve animal welfare standards also improve scientific rigor of experimental results. In an educational context, the best alternative would be to replace all animal use causing animal suffering, whilst still allowing ethical animal use. However, this training can and should be achieved by the use of ethical and scientifically validated alternative methods, as is the case in some areas of animal testing. When teaching practical skills in particular, the use of alternative methods helps to safeguard the student from acquiring undesirable attitudes towards animals, such as indifference to animal life and/or disregard for animals as patients. In veterinary medicine and animal sciences, the most suitable alternative to the use of animals in teaching is through the use of models, mannequins and simulators as well as multimedia computer simulations, including virtual reality, in addition to the use of ethically sourced animal cadavers and tissues $(8,15,37)$. Each is followed by complementary activities such as clinical work with patients intended to benefit from this approach. Thus, a student will begin by using early stage alternatives such as models, before moving on to simulators and more advanced alternatives, and finally dissection of ethically sourced animal cadavers and tissues. Only after these phases are successfully completed will the student be allowed to take part in initial clinical work with animal patients. In this way, students are exposed to a richer educational experience (in the different disciplines and academic semesters) in which students can obtain an adequate level of training, with added confidence in their work, whilst maintaining respect for life and the individual animal.

Models, mannequins and simulators: These models are already widely available for teaching morphology, orthopedics, and related subjects. The models are fairly realistic and designed for clinical learning ability, including blood collection, intubation, thoracocentesis, CPR techniques and urinary catheterization. A canine example of such a model is Critical Care Jerry ${ }^{\circledR}$, which integrates a digital simulation of heart and lung sounds, in addition to allowing intubation, CPR, intravenous access, and other functions. The simulators are an essential tool for surgery, intensive care and some clinical techniques. As with the mannequins, simulators give students the freedom to practice according to their individual skill level, based on speed, learning by trial and error, and repeating the procedure at no welfare cost to an animal. Most mannequins possess artificial skin, bones and organs together with an artificial pulse and liquids that simulate blood and bile (15). When computerized, it is possible to recreate real-time emergencies, and to allow monitoring of the student's performance, also in real time, in practicing their surgical or critical care skills. It is also possible to study the effects of drug administration together with computer simulation, in order to study physiological dose dependent response (38).

Multimedia computerized simulators: Examples include virtual dissections and experiments in highly equipped laboratories (specially adapted for teaching physiology, pharmacology and intensive care) where the student can accomplish everything on the screen, but also virtual reality simulators for clinical techniques, where equipment is handled. Well-designed software can create a high level of understanding so as to increase understanding of specific topics according to individual needs (9). This type of material encourages individual exploration and problem-solving strategies that promote scientific thinking, initiative and creativity $(13,26)$.

Virtual reality: The term "Virtual reality" generally refers to advanced interactive software with powerful 3D graphics, which normally immerse the user in the experience and improves and enhances psychomotor function, and is a highly sensory procedure (32). In this instance, the student normally holds a device that simulates a needle-holder, a scalpel or an endoscope, where a particular procedure needs to be performed in a virtual patient. The School of Veterinary Medicine of the University of Glasgow has developed alternatives to invasive tests in animals as part of its commitment to animal welfare and to ensure better training for their students. Thus, for example, the palpation of ovaries in mares and cows is replaced by a virtual simulation that allows students to practice the palpation without running the risk of causing harm to an animal, and allows analysis of a variety of clinical cases (3).

Ethically sourced tissue and animal cadavers: The study of anatomy in veterinary medicine would not be complete without access to animal cadavers or animal tissues. These resources are also excellent tools for the practice of clinical and surgical techniques once the student has acquired the necessary skills from earlier nonanimal alternatives. The term "ethically sourced" refers to animal cadavers and tissues that have been obtained from animals that died from natural causes or else were euthanized strictly for medical reasons in response to a terminal illness or injury (15) and therefore, euthanasia 
was the best welfare option for the animal in question. In addition, for the acquisition to be considered ethical, it must not support a parallel market where these cadavers or tissues could be marketed (22).

The availability of ethically sourced cadavers will increase in independent veterinary clinics, veterinary hospitals, veterinary schools and other medical veterinary service centers once duly legalized. However, it is advisable to create a Donation Program, in which the client signs an informed consent document in order to donate the body of their pet, after its natural death or euthanasia. Students seem to better appreciate the study of anatomy and demonstrate more mature behavior with animal cadavers that have been donated by a client (18). If there is cooperation between the various university departments (e.g., pathology, anatomy and surgery), the use of these animals can be further enhanced.

The main goal of veterinary education is to provide new graduates with the clinical skills needed to provide the optimal care of animals. Later on, greater skills will be required for more invasive approaches for diagnosis and treatment. These objectives can be achieved by involving students directly in the diagnosis and treatment of real patients. This approach can be applied for the treatment and care of sick animals brought into the educational establishment by the client. For veterinary students, working with live animals is essential, but the animals must also benefit from the encounter. Clinical skills can be acquired using this approach. The student will also benefit from the diversity of patients and clinical situations, whilst improving their communication skills with colleagues and the owners of animals. However, in achieving these objectives and meeting required levels of care for the welfare of these animals, it is essential for clinical tutors to provide close supervision to ensure that all work performed on these animals is either benign or beneficial to the individual animal (29). Thus, only after the basic techniques have been taught (34) will the student be allowed to move on to more advanced stages, such as the use of ethically sourced animal cadavers, and finally to the living animal, who will benefit from competent diagnosis and medical treatment.

\section{Is it possible to be too caring and compassionate?}

Quoting the words of oncologist Dr. Ogilvie (25), "Compassion Fatigue" is responsible for the loss of some of the brightest and most astute veterinary professionals. While care and compassion are essential in the veterinary profession, it has been suggested that too intense an exposure to animal suffering has a price. There are, however, different strategies to combat this problem, the most effective being the conviction that one is doing one's best for the patient. This may not be a simple solution, but the veterinarian who can achieve it does not lose sight of the original reason for becoming a doctor-vet.

Related to this issue, if we look back to the learning experience at veterinary school, in which students were forced to cause suffering to animals and compromise their conscience, we may well be able to avoid compassion fatigue in the future. By using alternatives, students are taught that there is always another way, there will always be an "alternative" - a positive solution devoid of animal suffering (17). As we teach compassion for animals, we will produce more dedicated and motivated students and therefore better vets.

\section{Conclusion}

Schools of veterinary medicine and related life sciences require more investment so that all students can benefit from ethical and effective methods of acquiring knowledge and practical skills. Investment in alternative methods benefits all stakeholders - students, teachers, and animals, as well as the veterinary profession and society in general. Fortunately new generations of veterinary students will graduate having experienced the best possible teaching practices due to curricular and creative transformation. Future veterinary generations will completely embrace the rule: "Primum non nocere " (First, do no harm).

\section{References}

1. Abood SK, Slegford JM (2012): Student perception of an animal-welfare and ethics course taught early in the veterinary curriculum. J Vet Med Educ, 39, 136-141.

2. Anon (2010): Directive 2010/63/EU of the European Parliament and of the Council of 22 September 2010 on the protection of animals used for scientific purposes. Official Journal of the European Union L276, 20.10.2010, 33-79.

3. Baillie S, Mellor DJ, Brewster SA, et al. (2005): Integrating a bovine rectal palpation simulator into an undergraduate veterinary curriculum. J Vet Med Educ, 32, 85-91.

4. Bekoff M (2000): The Smile of a Dolphin: Remarkable Accounts of Animal Emotions. Discovery Books, New York.

5. Bekoff M (2005): Field Studies and Animal Models: Towards Non-invasive Approaches in Zoology Research and Teaching. In: $2^{\text {nd }}$ InterNICHE Conference: Alternatives in the Mainstream: Innovations in life science education and training. International Network for Humane Education, Leicester, UK.

6. Capaldo T (2004): The psychological effects on students of using animals in ways that they see as ethically, morally or religiously wrong. Altern Lab Anim, 32 (Supplement 1), 525-531.

7. Capaldo T (2005): The hidden curriculum in the harmful use of animals in science educations. In: 2nd InterNICHE Conference - Alternatives in the Mainstream: Innovations in life science education and training. International Network for Humane Education Leicester, UK. 
8. Cervinka RE, Cervinkova Z (2006): Alternatives to animal experimentation in undergraduate curricula at medical schools - analysis of current trends in the Czech Republic. ALTEX, 23, Spec. Issue, 46-50.

9. de Bie MH, Lipman LJ (2012): The use of digital games and simulators in veterinary education: An overview with examples. J Vet Med Educ, 39, 13-20.

10. de Boo J, Knight A (2005): Concepts in animal welfare: A syllabus in animal welfare science and ethics for veterinary schools. J Vet Med Educ, 32, 451-453.

11. Dewhurst DG, Hemmi A (2011): A survey of animal use and alternatives in higher education in Europe. ALTEX, 28, 227.

12. Dewhurst DG, Kojic ZZ (2011): Replacing animal use in physiology and pharmacology teaching in selected universities in Eastern Europe - charting a way forward. ATLA, 39, 15-22.

13. Haluck RS, Marshall RL, Krummel TM, et al. (2001): Are surgery training programs ready for virtual reality? A survey of program directors in general surgery. J Am Coll Surg, 193, 660-665.

14. International Network for Humane Education (InterNICHE) (2012): New testimonies of student conscientious objection. http://www.interniche.org/en/news /new-testimonies-student-conscientious-objection-online.

15. Jukes N, Chiuia M (2003): From Guinea Pig to Computer Mouse: Alternative Methods for a Progressive, Humane Education. International Network for Humane Education, Leicester, UK.

16. Knight A (2002): Learning without killing: A guide to conscientious objection. http://www.humanelearning.info/ resources.html\#books.

17. Knight A (2007): The effectiveness of humane teaching methods in veterinary education. ALTEX, 24, 91-109.

18. Kumar AM (2003): Client donation program to meet the needs of veterinary medical education: Alternatives to healthy animal sacrifice. 107-116. In: Jukes N, Chiuia M (Eds), From guinea pig to computer mouse: alternative methods for a progressive, humane education. International Network for Humane Education, Leicester, UK.

19. Lairmore MD, Ilkiw J (2015): Animals used in research and education, 1966-2016: Evolving attitudes, policies, and relationships. J Vet Med Educ, 42, 425-440.

20. Levine ED, Mills DS, Houpt KA (2005): Attitudes of veterinary students at one US College toward factors relating to farm animal welfare. J Vet Med Educ, 32, 481-490.

21. Main DC, Thornton P, Kerr K (2005): Teaching animal welfare science, ethics, and law to veterinary students in the United Kingdom. J Vet Med Educ, 32, 505-508.

22. Martinsen S, Jukes N (2005): Towards a humane veterinary education. J Vet Med Educ, 32, 454-460.

23. Martinsen S (2007): Training the animal doctor: Caring as a clinical skill. ALTEX, 14, 269-272.

24. Millman ST, Adams CL, Turner PV (2005): Animal welfare training at the Ontario Veterinary College. J Vet Med Educ, 32, 447-450.

25. Nolen RS (2006): When caring too much is an occupational hazard. J Am Vet Med Assoc News. https://www.avma.org/ News/JAVMANews/Pages/060601m.aspx.

26. Papalois AE (2009): Medical education. Modern methods and alternative methods to animal procedures. J Hellenic Vet Med Soc, 60, 233-236.
27. Pedersen H (2002): Humane education: Animals and alternatives in laboratory classes: aspects, attitudes and impact. 20-57. In: Pederesen H (Ed), Perspectives on human education and animal use: Educational and Pedagogical Aspects. Stiftelsen Forskning utan djurförsök, Stockholm.

28. Pedersen H (2007): The school and the animal other - an ethnography of human-animal relations in education. $\mathrm{PhD}$ thesis. Department of Education, University of Gothenburg, Sweden.

29. Rasmussen LM (2003): A pedagogically sound, innovative, and humane plan for veterinary medical education. 125-133. In: Jukes N, Chiuia M. (Eds), From guinea pig to computer mouse: Alternative methods for a progressive, humane education. International Network for Humane Education, Leicester, UK.

30. Russel WM, Burch RL (1992): The sources, incidence, and removal of in humanity. In: Russel WM, Burch RL (Eds), The principles of humane experimental technique. Universities Federation for Animal Welfare, the Wheathampstead, UK http://altweb.jhsph.edu/pubs/books/ humane_exp/chap4d.

31. Sachana M, Theodoridis A, Cortinovis C, et al. (2014): Student perspectives on the use of alternative methods for teaching in veterinary faculties. Altern Lab Anim, 42, 223-33.

32. Scalese RJ, Issenberg SB (2005): Effective use of simulations for the teaching and acquisition of veterinary professional and clinical skills. J Vet Med Educ, 32, 461467.

33. Schmidt A, Hohensee C, Teichgräber U, et al. (2011): SATIS ethics ranking of universities in Germany regarding animal use in education. ALTEX, 28, 243-244.

34. Smeak DD (2003): Ethical surgery training for veterinary students. 117-124. In: Jukes N, Chiuia M (Eds), From guinea pig to computer mouse: Alternative methods for a progressive, humane education. International Network for Humane Education, Leicester, UK.

35. Solot D, Arluke A (1997): Learning the scientist's role: Animal dissection in the middle school. J Contemp Ethnogr, 26, 28-54.

36. Sprecher DJ (2004): Insights into the future generation of veterinarians: Perspectives gained from the 13-and 14years-olds who attended Michigan State University's veterinary camp, and conclusions about our obligations. J Vet Med Educ, 31, 199-202.

37. Valliyate M, Robinson NG, Goodman JR (2012): Current concepts in simulation and other alternatives for veterinary education: A review. Vet Med Chech, 57, 325-337.

38. Zhang Q, Bhattacharya S, Andersen ME, et al. (2010): Computational systems biology and dose-response modeling in relation to new directions in toxicity testing. $\mathrm{J}$ Toxicol Environ Health B Crit Rev, 13, 253-276.

Geliş tarihi: 19.04.2016/Kabul tarihi: 01.11.2016
Address for correspondence:
Dr. Yasemin Salgırlı Demirbaș
Ankara University, Faculty of Veterinary Medicine
Department of Physiology,
06110, Dışkapı, Ankara, Turkey.
Tel.: +9031231703 15/4427
e-mail: yaseminsalgirli@gmail.com 